\title{
1 Subsidy Accessibility Drives Asymmetric Food Web Responses
}

3 Marie Gutgesell ${ }^{1}$, Bailey C. McMeans ${ }^{2}$, Matthew M. Guzzo ${ }^{1}$, Valesca deGroot ${ }^{3}$, Aaron T. Fisk ${ }^{5}$,

4 Timothy B. Johnson ${ }^{4}$, Kevin S. McCann ${ }^{1}$

5

$6 \quad{ }^{1}$ Integrative Biology, University of Guelph, Guelph ON, Canada

$7 \quad{ }^{2}$ Department of Biology, University of Toronto Mississauga, Mississauga ON, Canada

$8{ }^{3}$ Ocean Science Centre, Memorial University of Newfoundland, Logy Bay, NL, Canada

$9{ }^{4}$ Ontario Ministry of Natural Resources and Forestry, Glenora Fisheries Station, Picton, ON, Canada

$10{ }^{5}$ School of the Environment, University of Windsor, Windsor, ON, Canada 


\section{Abstract (max 350 words)}

13 Global change is fundamentally altering flows of natural and anthropogenic subsidies across space

14 and time. After a pointed call for research on subsidies in the 1990s, an industry of empirical work

15 has documented the ubiquitous role subsidies play in ecosystem structure, stability and function. Here, we argue that physical constraints (e.g., water temperature) and species traits can govern a species' accessibility to resource subsidies, and that these physical constraints have been largely overlooked in the subsidy literature. We examined the input of a high quality, point-source anthropogenic subsidy into a recipient freshwater lake food web (i.e., released net-pen aquaculture feed in Parry Sound, Lake Huron), to demonstrate the importance of subsidy accessibility in

21 governing recipient whole food web responses. By using a combined bio-tracer approach, we

22 detect a gradient in accessibility of the anthropogenic subsidy within the surrounding food web

23 driven by the thermal tolerances of three constituent species. This thermally-driven accessibility

24 gradient drives asymmetrical changes in food web structure, effectively rewiring the recipient lake

25 food web and altering patterns in secondary production with yet unknown stability consequences.

26 Since aquaculture is predicted to increase significantly in coming decades to support growing

27 human populations, and global change is altering temperature regimes, then this form of food web

28 alteration may be expected to occur frequently. We argue that subsidy accessibility is a key

29 characteristic of recipient food web interactions that must be considered when trying to understand the impacts of subsidies on ecosystem stability and function under continued global change.

32 Keywords: Subsidy accessibility, anthropogenic subsidies, food web structure, bio-tracers, stable

33 isotopes, fatty acids, net-pen aquaculture, lake 
Introduction

37 Ecosystems are intrinsically connected through space and time by flows of energy (i.e.,

38 subsidies) that ultimately help govern the receiving ecosystem's stability and function.

39 Foundational work by empirical ecologists in the late 1990's demonstrated the ubiquity of

40 natural subsidies (e.g., nutrients, detritus, prey) connecting landscapes across a broad range of

41 spatial and temporal scales (Polis \& Strong, 1996; Polis \& Winemillar 1996; Polis et al., 1997;

42 Sears et al., 2004). This empirical work led to theory demonstrating that subsidies are pivotal in

43 determining the stability and community composition of recipient food webs (Polis et al., 1997;

44 Huxel \& McCann, 1998; Sears et al., 2004, Takimoto et al. 2002). While subsidies occur

45 naturally, a growing human population is increasing the prevalence of anthropogenic subsidies

46 to natural ecosystems (e.g., agricultural nutrient run-off, sewage, net-pen aquaculture waste).

47 Akin to natural subsidies, anthropogenic subsidies also have the potential to influence recipient

48 food web dynamics (DeBruyn et al., 2004; Rodewald et al., 2011; Newsom et al., 2015; Singer

49 et al., 2016; Lee et al., 2018; Johnson et al., 2018; DeBruyn et al., 2020). As food web dynamics

50 govern whole ecosystem stability and function (de Ruiter et al., 1995; Neutel et al., 2002), it is

51 imperative to understand how recipient food webs respond to both natural and anthropogenic

52 subsidies under continued global change.

53 It is now well recognized that fluxes of subsidies play a major role across most

54 ecosystems (Leroux \& Loreau, 2008) and also ought to significantly impact the stability and

55 functioning of recipient ecosystems (Huxel \& McCann, 1998; Takimoto et al., 2002; Leroux \&

56 Loreau, 2008). An industry of empirical and theoretical research has emerged since Polis and

57 others introduced subsidies to food web theory in the 1990s with researchers exploring the 
58 various ways subsidies can impact recipient ecosystems. Research has concentrated on: i)

59 subsidy quality and quantity; ii) the temporal nature of subsidies (e.g., Nakano et al., 1999;

60 Nakano \& Murakami, 2001; Sears et al., 2004); iii) the role of subsidies in driving trophic

61 cascades (Huxel \& McCann, 1998), and; iv) the roles space and ecosystem type play in

62 governing subsidy flow rate, assimilation, and magnitude of resultant impacts on food web

63 dynamics (Leroux \& Loreau, 2008). While this research has made major progress, surprisingly

64 little work has looked at the role of species traits (e.g., thermal preference) and physical habitat

65 characteristics (e.g., water temperature) in determining subsidy accessibility, and how this may

66 govern whole food web responses. Since accessibility may allow us to better understand how

67 subsidies integrate into whole recipient webs this is a major gap in subsidy research.

68 While subsidies are generally thought to be ubiquitous in nature, it is less understood

69 how the physical location of a subsidy within a habitat or ecosystem impacts its ability to be

70 accessed and thus assimilated by members of the local food web. Subsidy accessibility, defined

71 as the degree of availability of subsidies to recipient species based on their physiological (e.g.,

72 thermal tolerance) and physical habitat limitations, can drive differential increases in

73 productivity throughout the receiving food web. According to optimal foraging theory, if

74 capable, species will alter their foraging behaviour to access the highest density/quality resource

75 available (i.e., also referred to as the Birdfeeder Effect at the community level (Eveleigh et al.,

76 2007)). However, species may be limited in their ability to respond to these changes in local

77 resource densities by traits, such as mobility and thermal tolerance. For example, subsidies

78 entering the nearshore zone of a temperate lake may be expected to be most easily accessed by

79 warm adapted fishes and least accessible to cold adapted species. Therefore, in the example

80 above, we may expect to see the greatest alteration in diet towards subsidies in warm water 
81 species and reduced or absent alteration in diet in cold water species. This type of asymmetrical

82 subsidy accessibility and uptake can in turn drive differential changes in productivity and thus

83 food web structure throughout whole recipient ecosystem. Here, we combine the ideas that

84 species optimally forage within their physical and physiological capabilities and the asymmetric

85 impacts of spatial subsidies on receiving food webs, to suggest that species' ability to access

86 subsidies can drive differential (or asymmetric) changes in food web productivity and structure.

87 In this study, we broadly examine the dispersal of a point-source anthropogenic subsidy into a

88 temperate lake food web that contains dominant mobile, generalist top predators from each of the three

89 thermal guilds (i.e., a gradient in trait responses from cold- to coo-1 to warm- water fish) (Magnuson et

90 al., 1990). We build off empirical evidence of assimilation of a high-quality anthropogenic subsidy in

91 our study system, released net-pen aquaculture feed (Johnson et al., 2018), to demonstrate how

92 accessibility to this subsidy is key in governing the receiving food web's response to this novel

93 anthropogenic energy source. Differential accessibility throughout the recipient food web has the

94 potential to differentially alter productivity and thus asymmetrically alter food web structure (e.g.,

95 differential changes in food chain length). As changes in food web structure can drive alterations in

96 food web dynamics, this is a key first step in understanding how subsidy accessibility may ultimately

97 influence food web stability. Here, we use a combined bio-tracer approach to trace the fate of the

98 anthropogenic subsidy throughout the lake food web, and then combine hydroacoustic, fish biomass,

99 and stable isotope data to detect asymmetrical shifts in food web productivity and structure (i.e., food

100 chain length) across a thermal gradient.

\section{Methods}

102 Site Description 

investigate how accessibility to a point-source anthropogenic subsidy influenced assimilation into a surrounding food web and alterations in subsequent food web productivity and structure.

This location presents an ideal study system to address this question as there is a large feed \& waste from Aqua-Cage Fisheries Ltd.). Rainbow trout are reared within the Aqua-Cage net-pens and are fed daily from feed boats that move between cages from 9:00-16:00 each day

110 (Kana Upton, Aqua-Cage Fisheries Ltd., Pers. Comm). Feed consists of pelleted food 111 manufactured from both aquatic and terrestrial energy sources (see Appendix 1: Table S1 and

112 Table S2 for composition of the fish feeds). Parry Sound undergoes thermal stratification during

113 summer, which creates a natural thermal gradient from the near-shore, warm littoral zones (that

114 are more accessible to fishes with warmer thermal preferences) to the off-shore, cold pelagic

115 zones (that are more accessible to fishes with colder thermal preferences). The location of the

116 point-source subsidy in the deep, cold region of the lake thus sets up a natural gradient of

117 accessibility to the net-pen feed from most accessible (cold-water species), intermediate

118 accessibility (cool-water species), to least accessible (warm-water species).

To determine if any changes in diet and food web structure in Parry Sound were in fact

120 driven by differential assimilation of net-pen feed, we selected multiple control sites around

121 Georgian Bay, Lake Huron (see Appendix 1: Figure S1 for map). Control sites were selected by

122 the following criteria: no presence of off-shore point-source anthropogenic subsidy, far distance

123 to ensure no mixing of populations between subsidy and control sites, and presence of

124 comparable species. One control site was sampled in 2016 (Shawaniga/Sturgeon Bay) and three

125 control sites were sampled in in 2017 (Shawniga/Sturgeon Bay, Key Harbour, and Dyers Bay). 


\section{Fish \& Baseline Sampling}

Muscle tissue samples were collected from fish and whole invertebrates for stable isotope (SI) and fatty acid (FA) analysis from both Parry Sound and control sites in 2016 and 2017. Fish and invertebrate species were selected to recreate a tri-trophic generalist lake food web that contains a dominant generalist top predator in all three thermal guilds (lake trout (cold), walleye (cool), smallmouth bass (warm)), cold off-shore (alewife \& rainbow smelt) and cool near-shore (yellow perch) forage fish, and off-shore/near-shore baseline invertebrates. Figure 1 shows conceptual diagram of the tri-trophic generalist lake food web sampled.

Fish samples were collected using Ontario multi-mesh gill nets following a modified broad-scale monitoring (BsM) protocol of the fish community (Sandstrom et al., 2013) and supplemented with targeted angling. Both overnight and daytime sets were employed in the sampling protocol. All gill nets were set for a duration of $\sim 12 \mathrm{~h}$ before retrieving fish. Weight $(\mathrm{g})$, length $(\mathrm{mm})$, and two muscle tissue plugs from behind the dorsal fin were collected from fish. Non-predatory insect larvae (i.e., Ephemeroptera larvae), snails and mussels (Unionidae sp., and Dreissena polymorpha) were collected from each sampling site to provide baseline stable isotope values. Additionally, feed and muscle tissue from farmed rainbow trout was also collected each year Aqua-Cage Fisheries in Parry Sound. All samples were stored at $-20^{\circ} \mathrm{C}$ after collection until further analysis.

One muscle tissue plug from all fish, feed, and baseline samples collected were prepared for stable isotope analysis. Samples were thawed in the lab and dried at $60^{\circ} \mathrm{C}$ in a drying oven for $48 \mathrm{~h}$. Once dried, they were individually ground using a mortar and pestle and scooped into a labelled centrifuge tube. The samples were sent to the University of Windsor GLIER (Windsor, ON, Canada) laboratories for carbon and nitrogen isotopic analysis. Muscle tissues from a subset 
149 of the fish collected were sent for fatty acid analysis, along with feed and baseline samples.

150 Frozen samples were delivered to Ryerson University - The Arts Lab (Toronto, ON, Canada) in

151 2016, and both the Laboratory of Aquatic Sciences (Chicoutimi, QC, Canada) and Lipid

152 Analytical Services (Guelph, ON, Canada) in 2017. All labs conducted fatty acid analysis using

153 a combination of Bligh \& Dyer and Morrison \& Smith methods (Bligh \& Dyer, 1959; Morrison

154 \& Smith, 1964). Individual FA weights (ug/g) were converted to a \% FA composition and fatty

155 acids with $>1 \%$ presence were retained for analysis.

156 Detecting Assimilation of Net-Pen Subsidy into Surrounding Food Web

157 To determine which fatty acids were key indicators of net-pen aquaculture feed (i.e.,

158 fatty acids that are known to be primarily dietary-derived and are significantly higher or lower in

159 the feed than in natural surrounding prey sources) a principal components analysis (PCA) was

160 conducted on fatty acids with $>1 \%$ average proportions present in forage fish, feed, and baseline

161 fatty acid profiles from all sites. Fatty acid \% were standardized to a mean of zero and unit

162 variance prior to their inclusion in the PCA, and separate PCAs were performed for 2016 and

1632017 because different fish feeds with different compositions were used in each year (see

164 Supplementary Table 1, Table 2, \& Figure 2). Fatty acids with significant loadings $(>+/-0.3)$

165 along PC1 (indicating significantly higher amounts in feed than natural food sources) were

166 retained as Feed Indicator Fatty Acids (FIFA).

FIFA composition of each individual species was then compared between net-pen and

168 control sites using PCAs. The goal of this analysis was to determine if there was distinct

169 clustering of net-pen and control populations driven by the FIFA. To test whether the distance

170 between the net pen and control sites increased from warm to cool to cold water species

171 (reflecting increasing access to and assimilation of the net-pen subsidies), we compared the 
172 Euclidean distance between the centroids of the clusters within the PCA. PERMANOVA was

173 used to test for significant differences in the \% FIFA composition between net-pen and control

174 sites for each species (Anderson, 2017). As this technique yields pseudo-F statistics, P-values

175 can be calculated using permutations that yield P-values with significance considered for

$176 \mathrm{P}<0.05$. Due to the small and differing sample sizes, we conducted 100,000 permutations to

177 compute a nonparametric PERMANOVA (Steeves et al., 2018). Univariate boxplot comparisons

178 were used to identify which FIFA were driving significant differences in FIFA profiles.

179 Detecting Local Changes in Recipient Food Web Biomass Densities

Hydroacoustic surveys were conducted in 2017 to determine the horizontal and vertical

181 spatial distribution of fish surrounding the net-pen facility to detect local aggregations of fish

182 densities surrounding the point-source subsidy input, indicating potential local increases in

183 productivity. One day and one night survey was conducted on July 5 (day survey from 14:30-

184 19:00) and July 6 (night survey from 23:45 - 04:00) 2017 following a $2000 \mathrm{~m}$ transects leading

185 away from the net-pen facility (see map inset in Fig. 6). All surveys were conducted following

186 the standard operating procedures outlined in Parker-Stetter et al. (2009) (see Appendix 2 for

187 method details).

To determine if there were significantly higher densities of fish closer to the point-source

189 subsidy input location, Echoview acoustic post-processing software version 7.1.36.30718 was

190 used to convert the cleaned fish count data into fish density values (see Supplementary Methods

191 for details). Fish density values were extracted from Echoview and linear regressions $(\mathrm{a}=0.05)$

192 were conducted to compare fish density to distance from net-pen for both night and day surveys.

193 Non-linear data was log transformed prior to statistical analysis.

194 Detecting Regional Changes in Receiving Food Web Biomass 
Fish biomass data from five sites across Georgian Bay (Fig. 7) were obtained from the MNRF's 2017 Broad-scale Monitoring program (see UGLMU, 2018 for detailed collection methods), to determine if the off-shore net-pen subsidy in Parry Sound drove asymmetrical increases in the cold water, off-shore (pelagic) biomass. Biomass proportions of all species caught in the 2017 BsM sampling was extracted from the MNRF Annual Report of Fisheries Assessment Projects Conducted on Lake Huron, 2017 and sorted into a thermal guild based on their thermal preference (Hasnian et al., 2018). Species with final temperature preferendum (FTP, the temperature that fish gravitate towards when provided with a broad range of temperatures (Hasnain et al., 2018)) $<17^{\circ} \mathrm{C}$ were classified as cold, $17-25^{\circ} \mathrm{C}$ were classified as cool, and $>25^{\circ} \mathrm{C}$ were classified as warm (Coker et al., 2001). Total proportion of each thermal guild and proportion of each individual species was calculated. Distribution of total biomass across thermal guilds and species was then compared to see if Parry Sound had disproportionately higher biomass in the cold, off-shore thermal guild relative to sites with no net-pen facilities.

\section{Detecting Changes in Receiving Food Web Structure}

210 To detect alterations in food web structure driven by the point-source subsidy in Parry Sound, we

211 compared the trophic position of the representative food web collected from Parry Sound and control

212 sites in 2016 and 2017 using a carbon and nitrogen two-source stable isotope mixing model (Post,

213 2002). There is little to no fractionation of $\delta^{13} \mathrm{C}$ and is used to track basal energy sources (i.e., \%

214 littoral carbon use), while $\delta^{15} \mathrm{~N}$ fractionates from resource to consumer and thus is used to track

215 trophic position. To increase the number of control sites, additional $\delta^{15} \mathrm{~N}$ and $\delta^{13} \mathrm{C}$ data was obtained

216 for comparable species from numerous control sites around Lake Huron in 2017 as part of various

217 OMNRF research projects (UGLMU, 2018) (see Appendix 1: Figure S1 for map of sites). All 
218 information regarding collection of these samples can be found in the OMNRF Annual Report of

219 Fisheries Assessment Projects Conducted on Lake Huron, 2017 (UGLMU, 2018). Non-lipid corrected

$220 \mathrm{C}$ and $\mathrm{N}$ values were used as the majority of $\mathrm{C}: \mathrm{N}$ were low $(81 \%<3.5$ and $92 \%<4)$ (Post et al., 221 2007).

The following equations were used to calculate trophic position for the mobile, generalist top predators, which incorporate coupling of pelagic and littoral energy channels ((Post, 2002):

$$
\begin{gathered}
T P_{\text {Predator }}=2+\left(\delta^{15} N_{\text {predator }}-\left(\delta^{15} N_{\text {pelagic baseline }} *(1-\alpha)+\delta^{15} N_{\text {littoral baseline }} * \alpha\right)\right) / 3.4 \\
\alpha=\left(\delta^{13} C_{\text {predator }}-\delta^{13} C_{\text {pelagic baseline }}\right) /\left(\delta^{13} C_{\text {littoral baseline }}-\delta^{13} C_{\text {pelagic baseline }}\right)
\end{gathered}
$$

where $\delta^{15} \mathrm{~N}_{\text {predator }}$ and $\delta^{13} \mathrm{C}_{\text {predator }}$, are the nitrogen and carbon stable isotope values for predatory

227 fish collected (lake trout, walleye, smallmouth bass) and $\delta^{15} \mathrm{~N}_{\text {pelagic baseline, }} \delta^{13} \mathrm{C}_{\text {pelagic baseline, }}, \delta^{15} \mathrm{~N}$

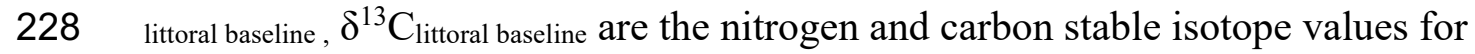

229 mussels/zooplankton and mayflies respectively. Coupling is incorporated into trophic position

230 calculation through $\alpha$, which weighs the trophic position estimate according to baseline

231 contributions (Vander Zanden et al., 1999; Vander Zanden et al., 2000).

not incorporate coupling (Post, 2002):

$$
\text { TP Intermediate Consumer }=2+\left(\delta^{15} N_{\text {prey fish }}-\left(\delta^{15} N_{\text {baseline }}\right)\right) / 3.4
$$

235 where $\delta^{15} \mathrm{~N}_{\text {prey fish }}$ and $\delta^{15} \mathrm{~N}_{\text {baseline }}$ are the nitrogen stable isotope values of forage fish and 
All statistical analysis was completed using the R statistical computing package, version

3.6.1 (R Core Team 2019). Full raw data and associated R code will be available on GitHub

241 upon manuscript acceptance.

\section{Results}

244 Net-pen Aquaculture Feed Indicator Fatty Acid Selection

PCA of all fatty acids (FA) composing $>1 \%$ of total FA composition for each forage fish,

246 baseline, and feed sample from net-pen and control sites in 2016 and 2017 successfully

247 separated net-pen feed sources from natural biota across PC1 (Fig 2. (a), (b)). PC1 explained

$24838.3 \%$ of total variation of fatty acid composition in 2016 and $38.8 \%$ in 2017 . This variance was

249 primarily driven by 3 FA in 2016 (higher \% in feed: 18:2n6, 18:1n9, 20:1n9), and 4 FA in 2017

250 (higher \% in feed: 18:2n6, 18:3n3, 18:1n9, 16:1n7), which all loaded significantly onto PC1 and

251 in the direction of the net-pen feed (i.e., PC score $>0.3$ ). These FA were retained as 'feed

252 indicator fatty acids' (FIFA) to be used in subsequent analysis comparing individual species

253 FIFA compositions between net-pen and control sites.

254 Asymmetrical Uptake of Net-Pen Subsidies Across Thermal Guilds

PCA on FIFA profiles of individual species between net-pen and control sites in 2016 and

2562017 show differences in the degree of separation of net-pen and control populations among thermal

257 guild and trophic level. The cold-water top predator (Fig. 4(a; i)) and forage fish (Fig. 4(b; $i)$ ), as well

258 as the cool-water forage fish (Fig. 3(d; $i)$; Fig. 4(c; $i)$ ) demonstrate the highest degree of separation

259 between net-pen and control populations. The cool-water top predator demonstrates some degree of

260 separation between net-pen and control populations (Fig. 3(a; i); Fig. 4(c; $i)$ ), and the warm-water top

261 predator shows some separation of populations in 2016, but a complete overlap with control 
populations in 2017 (Fig. 3(b; i); Fig. 4(d; i)). Euclidean distances between cluster centroids of net-pen and control populations demonstrate a negative relationship between species thermal preference (i.e.,

264 FTP) and centroid distance, where cold water species tend to have the greatest distance between

265 populations and warm water species the least (Figure 5).

PERMANOVA comparing the \% FIFA composition between net-pen and control populations

267 of each species shows that cold-water top predators $(p=0.0036)$, cold-water forage fish $(p=0.0304)$

268 and cool water forage fish $(p=0.0343)$ have the most significantly different FIFA profiles relative to

269 control sites in 2017. The 2016 cool-water forage fish population had the most significant difference in

270 FIFA populations across both years $(p=0.0008)$. In the cold-water top predator and forage fish these

271 significant differences are driven by higher levels of linoleic acid (18:2n6) and linolenic acid (18:3n3)

272 in net-pen populations relative to control (Fig. 4, (a; ii); (b; ii)). In the cool-water forage fish,

273 significant differences are driven by higher levels of all FIFA in net-pen populations for both 2016 and

274 2017. The cool-water top predator (i.e., Walleye) net-pen associated FIFA composition was

275 significantly different from control populations in $2017(p=0.0384)$ but not in $2016(p=0.378)$.

276 Consistent with cold-water species, Walleye also demonstrated higher levels of linoleic acid (18:2n6)

277 and linolenic acid (18:3n3) in net-pen populations relative to control in 2017 (Fig. 4, (c; $i i)$ ). Despite

278 not demonstrating significant differences in overall FIFA profiles in 2016, univariate boxplots show

279 Walleye still exhibited higher levels of FIFA relative to the control population (Fig. 3, (a; $i i)$ ), The

280 warm-water top predator (i.e., Smallmouth bass) showed no difference in FIFA profiles in 2017 ( $p=$

$2810.633)$ and a marginally significant difference in all 3 FIFA in $2016(p=0.056)$. Univariate boxplots

282 results show that this marginal significance was driven by higher levels of all 3 FIFA in 2016 net-pen

283 associated smallmouth bass. 
Linear regression of fish density surrounding net-pen facility demonstrate increased local

297 cold-water species that were much less abundant throughout the Georgian Bay (see Supplementary

298 Table 3 for \% biomass of species at sites across Georgian Bay).

$303=<0.001 ; \mathrm{F}=48.582, p=<0.001$, respectively) (Figure $6(\mathrm{a}),(\mathrm{d})$ ). Cool-water top predators and

304 forage fish exhibited significant differences in trophic position between sites across Lake Huron $(F=$

305 15.352. $p=<0.001 ; \mathrm{F}=18.878, p=<0.001$, respectively), however this significance was not driven by 
0.06219) (Fig. 6(c).) It should be noted that the MNRF data only included pelagic baselines, therefore coupling was not possible to calculate and incorporate into trophic position calculation of MNRF sampled generalist predators. Statistical outcomes were consistent regardless of if coupling was

311 incorporated or not, thus coupling was incorporated where possible to provide more accurate trophic

312 position estimates when able.

\section{Discussion}

Despite the fact that accessibility may fundamentally alter the influence of a subsidy on resultant food web dynamics, surprisingly this aspect of subsidies remains relatively unexplored. Here, we use a natural experiment to determine how species traits, particularly thermal tolerance, influenced accessibility to an off-shore point-source anthropogenic subsidy, and in turn show that differential

318 accessibility drives asymmetric changes in food web productivity and structure. Our results suggest that species traits can produce a gradient in subsidy accessibility, as cold-water adapted species show the greatest evidence of subsidy consumption, and warm-water species demonstrate little to none.

321 Notably, our feeding results also scale up to show consistent asymmetric changes in productivity and

322 food web structure such that cold-water species, for example, consume most of the subsidy and have 323 elevated biomass and trophic position. impacts on habitat (e.g., habitats differentially warmed by climate change) that lead to organismal

326 behaviour that asymmetrically rewires whole carbon pathways. Bartley et al (2018) argued that

327 differential habitat changes and species behaviour (traits) then drive wholesale food web rewiring. Our 328 results here suggest that such impacts of climate change rewiring may extend more broadly to other 329 aspects of global change. Specifically, here we showed that the placement of net-pen aquaculture in 330 cold-water habitats (i.e., a global change that is necessarily habitat dependent and so asymmetrical) 
331 produces stronger interactions as a function of species traits (i.e., thermal tolerance) and so

332 functionally rewires this ecosystem, altering food web structure and productivity with yet unknown

333 stability implications (Blanchard et al., 2015; Bartley et al. 2018). Like climate change, net-pen inputs

334 can differentially alter macrohabitats (littoral versus pelagic) and so drive asymmetric rewiring. It

335 remains to be seen whether human impacts that cross multiple habitats generally have asymmetrical

336 impacts, and if they do, this suggests a general rewiring result of global change on spatial food webs.

337 The use of fatty acids to trace specific prey items through food webs has provided a powerful

338 tool for understanding how subsidies move through and are utilized by the surrounding ecosystem.

339 Fatty acid composition analysis has been widely used in the aquaculture literature to identify the

340 presence of net-pen feed in the diet of surrounding fish species in both marine and freshwater systems

341 (Kullman et al., 2009; Fernandez-Jover et al., 2011; Johnson et al., 2018). The presence of marine and

342 terrestrial derived protein and oil in fish feed differentiate the fatty acid composition of the feed from

343 natural food sources (Fernandez-Jover et al., 2011). Fatty acids are highly conserved throughout the

344 food web, which provides the ability to trace net-pen feed through a surrounding food web because

345 differences in fatty acid composition between net-pen and control populations is proportional to the

346 amount of feed consumed (Fernandez-Jover et al., 2011).

We demonstrated how subsidy accessibility, measured through amount of consumption of net-

348 pen feed, depends on species' traits (e.g., thermal tolerance). Cold-water mobile generalists and forage

349 fish had significant differences in feed indicator fatty acid (FIFA) composition relative to control

350 populations (little overlap in FIFA clusters, large centroid distance (Fig. 4; Fig. 5)). This suggests their

351 diet is significantly different from control diets due to the presence of feed. Cold-water forage fish

352 were less significantly different than the mobile generalist, which may be a factor of the different

353 dominant pelagic forage fish found in each locations (Alewife in Parry Sound, Rainbow Smelt in 
354 Dyer's Bay). In our study, cool-water forage fish had the most significant difference in FIFA profile in 355 2016, and while still significant in 2017, not as significant as the cold-water generalist and forage fish.

356 Cool-water mobile generalists' FIFA profiles were also significantly different from control

357 populations, however the signal was not as strong (centroid distance not as far, more cluster overlap)

358 as in the cold-water species. The cool-water generalist and forage fish also displayed higher variation

359 in the Parry Sound populations relative to controls and cold-water species. This suggests there may be

360 more individual variation in the cool-water guild, where some individuals strongly incorporate FIFA

361 and some were no different than other control fish. Warm-water mobile generalists demonstrated high

362 overlap between net pen and control sites, suggesting little to no feed uptake and low access to net-pen

363 subsidies in 2017. Marginally significant differences between net pen and control sites in 2016

364 indicate some individuals may have accessed net-pen subsidies that year. Some evidence of access in

3652016 may be due to warmer temperatures that summer (Parry Sound Historical Weather Data,

366 Environment Canada), which may have made a larger warmer zone and thus able to forage farther and

367 potentially access net-pen resources. It should be noted that littoral baselines (i.e., mayflies) had

368 similar values of linolenic acid (18:3n3) and higher values of palmitoleic acid (16:1n7) relative to the

369 feed due to the input of terrestrial oils in the feed (Appendix 1: Figure S1). This may drive similarities

370 in FIFA profiles of littoral cool and warm water species; therefore, it is important to focus on fatty

371 acids that are significantly different from the feed as stronger feed indicators in these species. Here,

372 our results provide evidence of a gradient in net-pen feed uptake, that is correlated with the gradient in

373 thermal preferences, suggesting thermal tolerances limit the ability of surrounding species to access

374 point-source subsidies. Further, our results suggest the intriguing possibility that the population of

375 cold-water species (e.g. lake trout) generally respond to consume from the cold-water feed site, while 
more thermally generalized species (cool-water) show greater variation in response suggesting

377 individual variation in amount of feed intake.

By looking at changes in local and regional fish density and biomass patterns, we were able to

379 simultaneously detect asymmetrical increases in biomass of the surrounding food web along the accessibility gradient. These changes in biomass suggest asymmetrical access to net-pen resources may drive differential productivity in the surrounding food web (e.g., cold-water species elevated). Investigation into patterns of fish density surrounding the net-pen showed increased density locally around the net-pen, suggesting surrounding species aggregate to forage on the released net-pen subsidy. These aggregations were also stronger at night, when fish are actively foraging. Our results operations in both marine and freshwater systems (Ferndandez-Jover et al., 2007; Johnston et al.,

Parry Sound had a higher proportion of biomass of cold-water species relative to sites with no point-

393 biomass in the cold-water guild. However, here the guild is dominated by whitefish and there are no

394 lake trout present, it also supports a lower diversity of cold-water fish than Parry Sound (Appendix 1:

395 Table S3). The significantly higher proportion of offshore biomass in Parry Sound, and presence of a 396 naturally reproducing off-shore top predator that strongly accesses net-pen feed, suggests net-pen

397 subsidies may be increasing off-shore productivity. Further research investigating how these released 398 subsidies are influencing basal food web productivity (i.e., zooplankton biomass) will be helpful in 
elucidating the mechanism through which net-pen subsidies are driving significantly higher cold-water guild biomass in Parry Sound.

Through examination of trophic position of net-pen associated species and control species throughout Lake Huron, we detected significant increases in trophic position of cold-water species in species. As higher trophic positions indicate longer food chains (Vander Zanden et al., 1999), these results suggest that thermal guilds with the greatest accessibility to net-pen subsidies (in this case coldwater guild) have a significantly longer food chain than guilds with less access. Therefore, the gradient in subsidy accessibility drives asymmetric changes in surrounding food web structure (i.e., lengthening of cold water food chain, no lengthening of cool-warm water food chain). These results are supported by previous work conducted by Johnson et al. (2018) that provided the first evidence of higher trophic position in cold-water species in net-pen associated sites. Asymmetrical changes in food web structure

411 can fundamentally rewire whole food webs (Bartley et al., 2019), which influences whole food web

412 stability and function in yet unknown ways. As accessibility is a main driver of these asymmetric

413 changes in surrounding food web that may influence whole food web stability, our research highlights

414 the importance of looking at subsidy accessibility when trying to understand or predict subsidy-driven 415 food web dynamics.

416 Here, we provide the first evidence that accessibility gradients to subsidies do exist and can

417 largely influence the strength of subsidy assimilation and changes in resultant food web productivity

418 and structure. To determine if subsidy accessibility is ubiquitous across ecosystems (i.e., is this a

419 characteristic of subsidies that is always relevant), more empirical studies investigating this concept

420 are needed. Additionally, theoretical work focused on understanding how asymmetrical changes in 
421 productivity and structure based on differential accessibility scenarios influence food web stability and

422 function are needed to understand the dynamical implications of subsidy accessibility.

423 Global change and increasing human populations are continually altering the flow of natural

424 and anthropogenic subsidies throughout ecosystems, thus it is imperative to understand how these

425 subsidies, in combination with global changes, will influence future food web stability and function.

426 Elucidating key subsidy characteristics that drive changes in recipient food web structure and function

427 is essential. Here, we contribute another key subsidy characteristic, subsidy accessibility, that has yet

428 to be considered in subsidy literature. While this study shows how accessibility is key in determining

429 food web responses to an anthropogenic subsidy, we argue this concept can be more widely applied to

430 all subsidies and is a key characteristic of subsidy-receiving food web interactions that must be

431 considered when trying to understand subsidy impacts on receiving ecosystem stability and function

432 under continued global change.

\section{Acknowledgments}

434 This project was in part funded by the University of Guelph's Canada First Research Excellence Fund 435 project "Food from Thought," awarded to K.S.M, and from Aqua-Cage Fisheries Ltd. We would like

436 to thank the Ontario Ministry of Natural Resources and Forestry (OMNRF) and their multiple

437 sampling programs that contributed to this study. 


\section{Literature Cited}

445

446

447

448

449

450

451

452

453

454

455

456

457

458

459

460

461

462

463

464

465

466

Anderson, M. J. 2017. Permutational Multivariate Analysis of Variance (PERMANOVA). Wiley StatsRef: Statistics Reference Online:1-15.

Bartley, T., K. S. Mccann, and C. Bieg. 2018. Food web rewiring in a changing world.

Blanchard, J. L. A. A rewired food web. Nature 527, 7-8 (2015).

Coker, G. A., C. B. Portt, and C. K. Minns. 2001. Morphological and Ecological Characteristics of Canadian Freshwater Fishes. Canadian Manuscript Report of Fisheries and Aquatic Sciences 2554:iv+89.

DeBruyn, A. M. H., D. J. Marcogliese, and J. B. Rasmussen. 2003. The role of sewage in a large river food web. Canadian Journal of Fisheries and Aquatic Sciences 60:1332-1344.

Debruyn, A. M. H., K. S. Mccann, J. B. Rasmussen, A. M. H. Debruyn, K. S. Mccann, and J. B. Rasmussen. 2020. Migration Supports Uneven Consumer Control in a Sewage-Enriched River Food Web Published by : British Ecological Society Linked references are available on JSTOR for this article : Migration supports uneven consumer control in a sewage-enriched river food 73:737-746.

Eveleigh, E. S., K. S. McCann, P. C. McCarthy, S. J. Pollock, C. J. Lucarotti, B. Morin, G. a. McDougall, D. B. Strongman, J. T. Huber, J. Umbanhowar, and L. D. B. Faria. 2007. Fluctuations in density of an outbreak species drive diversity cascades in food webs. Proceedings of the National Academy of Sciences 104:16976-16981.

Fernandez-Jover, D., P. Sanchez-Jerez, J. T. Bayle-Sempere, C. Valle, and S. Derrien. 2008. Seasonal patterns and diets of wild fish assemblages associated with Mediterranean coastal fish farms. ICES Journal of Marine Science 65:1153-1160. 
467 Hasnain, S. S., M. D. Escobar, and B. J. Shuter. 2018. Estimating thermal response metrics for North American freshwater fish using Bayesian phylogenetic regression. Canadian Journal of Fisheries and Aquatic Sciences 75:1878-1885.

470 Huxel, G. R., K. McCann, and G. a. Polis. 2002. Effects of partitioning allochthonous and autochthonous resources on food web stability. Ecological Research 17:419-432.

Johnson, L. E., B. McMeans, N. Rooney, M. Gutgesell, R. Moccia, and K. S. McCann. 2018. Webs 15:e00084.

Lee, K. Y., L. Graham, D. E. Spooner, and M. a. Xenopoulos. 2018. Tracing anthropogenic inputs in stream foods webs with stable carbon and nitrogen isotope systematics along an agricultural

Leroux, S. J., and M. Loreau. 2008. Subsidy hypothesis and strength of trophic cascades across ecosystems. Ecology Letters 11:1147-1156.

McCann, K. S. 2005. The dynamics of spatially coupled food webs:513-523.

481 Nakano, S., and M. Murakami. 2001. Reciprocal subsidies: Dynamic interdependence between terrestrial and aquatic food webs. Proceedings of the National Academy of Sciences of the United States of America 98:166-170.

Newsome, T. M., J. a. Dellinger, C. R. Pavey, W. J. Ripple, C. R. Shores, A. J. Wirsing, and C. R. Ecology and Biogeography 24:1-11. 
Polis, G. a., W. B. Anderson, and R. D. Holt. 1997. Toward an integration of landscape and food web ecology: The dynamics of spatially subsidized food webs. Annual Review of Ecology and Systematics 28:289-316.

Polis, G. a., and D. R. Strong. 1996. Food web complexity and community dynamics. American Naturalist 147:813-846.

Post, D. M. 2002. Using stable isotopes to estimate trophic position: models, methos, and assumptions. . Ecology 83:703-718.

Post, D. M., C. A. Layman, D. A. Arrington, G. Takimoto, J. Quattrochi, and C. G. Montaña. 2007. isotope analyses. Oecologia 152:179-189.

Rennie, M. D., P. J. Kennedy, K. H. Mills, C. L. Podemski, C. M. C. Rodgers, C. Charles, L. E. aquaculture on fish communities : A whole- - ecosystem experimental approach:870-885.

Rodewald, A. D., L. J. Kearns, and D. P. Shustack. 2011. Anthropogenic resource subsidies decouple predator-prey relationships. Ecological Applications 21:936-943.

506 Productivity. Pages 359-386 in G.A. Polis, G.R. Huxel and M.Power, eds. Food Webs at the

507 Landscape Scale: The Ecology of Trophic Flow across Habitats. University of Chicago Press,

\section{Chicago, IL.}

509 Steeves, H. N., B. McMeans, C. Field, C. Stewart, M. T. Arts, A. T. Fisk, C. Lydersen, K. M. Kovacs, 510 and M. A. Macneil. 2018. Non-parametric analysis of the spatio-temporal variability in the fatty511 acid profiles among Greenland sharks. Journal of the Marine Biological Association of the United 
Kingdom 98:627-633.

513 Takimoto, G., T. Iwata, and M. Murakami. 2002. Seasonal subsidy stabilizes food web dynamics:

514 Balance in a heterogeneous landscape. Ecological Research 17:433-439.

515 Upper Great Lakes Management Unit (UGLMU). (2018). Annual Report of Fisheries Assessment

516 Projects Conducted on Lake Huron, 2017. Ministry of Natural Resources and Forestry, Report

$517 \quad$ PS-LHA-2017-01.

518 Vander Zanden, M. J., and J. B. Rasmussen. 1999. Primary Consumer 13 C and 15 N and the Trophic

519 Position of Aquatic Consumers. Ecology 80:1395-1404.

520 Vander Zanden, M. J., B. J. Shuter, N. Lester, and J. B. Rasmussen. 1999. Patterns of food chain

521 length in lakes: A stable isotope study. American Naturalist 154:406-416.

522

523

524

525

526

527

528

529

530

531

532

533

534 
535 Figure 1. Conceptual figure of food web interactions within (a) natural temperate lake food web and (b) a temperate lake food web with a pelagic point-source anthropogenic subsidy input,

537 which here is released net-pen feed. It is predicted that net-pen feed will alter food web structure

538 through asymmetric accessibility to surrounding food web. Therefore, we expect to see strong

539 assimilation of net-pen feed in cold water fish and subsequent increases in trophic level and

540 biomass. It is expected that some assimilation occurs in cool water fish, and no assimilation of

541 net-pen feed occurs in warm water guild.

542 Figure 2. Principal component analysis of fatty acids $>1 \%$ of total fatty acid composition of all prey

543 fish, baseline, and feed samples analyzed in (a) 2016 and (b) 2017. Feed separated from lake biota

544 (except for littoral baselines) along PC1 in both 2016 and 2017. 2016 feed was separated by 3 FA

545 (higher levels of 18.2n6, 18.1n9, 20.1n9). In 2017, feed was separated by 4 FA (higher levels of

$546 \quad 18.2 \mathrm{n} 6,18: 3 \mathrm{n} 3,18.1 \mathrm{n} 9$, and $16: \ln 7)$

547 Figure 3. (i) PCA and (ii) univariate boxplot comparisons of feed indicator fatty acids (FIFA)

548 for (a) cool and (b) warm generalist, top predators and (c) cool water forage fish collected from

549 Parry Sound (PS) (anthropogenic subsidy input site) and control sites (Shawanaga Bay, SHN) in 5502016.

$551 \quad$ Figure 4. (i) PCA and (ii) univariate boxplot comparisons of feed indicator fatty acids (FIFA)

552 for (a) cold, (c) cool, and (e) warm generalist top predators, and (b) cold and (d) cool water

553 forage fish collected from Parry Sound (PS) (anthropogenic subsidy input site) and control sites

554 (Dyers Bay, DB; Shawanaga Bay, SHN; Key Harbour, KH) in 2017.

555 Figure 5. Euclidean distance between centroids of net-pen and control sites, calculated

556 separately for each species and year, in relation to species' final temperature preference. Blue 
represents species in the cold thermal guild, yellow and orange are species in the cool thermal guild, and red is species in the warm thermal guild.

559 Figure 6. Change in fish density (fish count $/ \mathrm{m}^{2}$ ) relative to distance from net-pen facility (m) in Parry

560 Sound for (a) day time transect and (b) night time transect in July 2017. Map inset shows transect

561 location in relation to net-pen facility in Parry Sound (red box), Georgian Bay. Fish density declined

562 with increasing distance from net-pen during the day, however this decline was not significant

$563\left(\mathrm{R}^{2}=0.158, \mathrm{p}=0.0821\right)$. Fish density significantly declined with increasing distance from net-pen

564 facility at night $\left(\mathrm{R}^{2}=0.43, \mathrm{p}<0.0001\right)$.

565 Figure 7. Distribution of biomass proportion across thermal guilds of all species collected from

566 MNRF BSM sampling in Georgian Bay, Lake Huron in 2017. Thermal guilds are indicated by colour,

567 asterisks next to site name indicate sites with presence of net-pen facility. Parry Sound and South Bay,

568 both of which contain net-pen aquaculture facilities, demonstrate higher proportion of species biomass

569 in the cold thermal guild (off-shore species) relative to control sites. Specifically, cold water species

570 biomass in Parry Sound is 2.0 - 7.9 times higher than control sites sampled throughout Georgian Bay,

571 where no net-pen aquaculture facilities were located. High relative biomass of cold water species in

572 Parry Sound to control sites was not reflected in the cool and warm water guilds.

573 Figure 8. Trophic position of (a) cold, (b) cool and (c) warm generalist top predators, and (d) cold and

574 (e) cool water forage fish collected from Parry Sound (indicated in red) and control sites in 2017.

575 Samples are a combination of those collected by our research team and the MNRF. Asterisks indicate

576 significant differences based on Tukey post-hoc analysis. 
bioRxiv preprint doi: https://doi.org/10.1101/2020.11.09.374629. this version posted November 10,2020. The copyright holder for this preprint (which was not certified by peer review) is the author/funder, who has granted bioRxiv a license to display the preprint in perpetuity. It is made available under aCC-BY-NC-ND 4.0 International license.

Figures

581

\section{Figure 1}

A) Temperate Lake Food Web

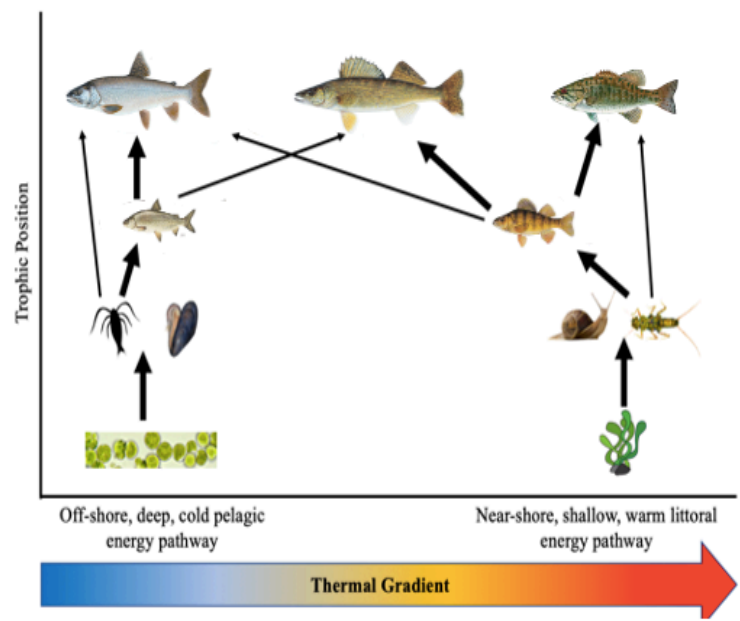

B) Temperate Lake Food Web with Pelagic Point-Source Anthropogenic Subsidy Input

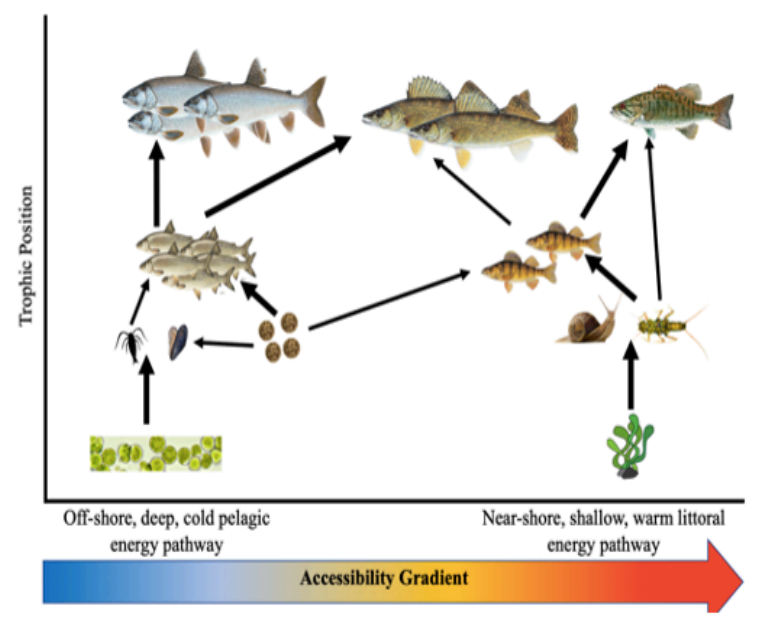

582

583 
bioRxiv preprint doi: https://doi.org/10.1101/2020.11.09.374629; this version posted November 10, 2020. The copyright holder for this preprint (which was not certified by peer review) is the author/funder, who has granted bioRxiv a license to display the preprint in perpetuity. It is made available under aCC-BY-NC-ND 4.0 International license.

\section{$584 \quad$ Figure 2}

(a)

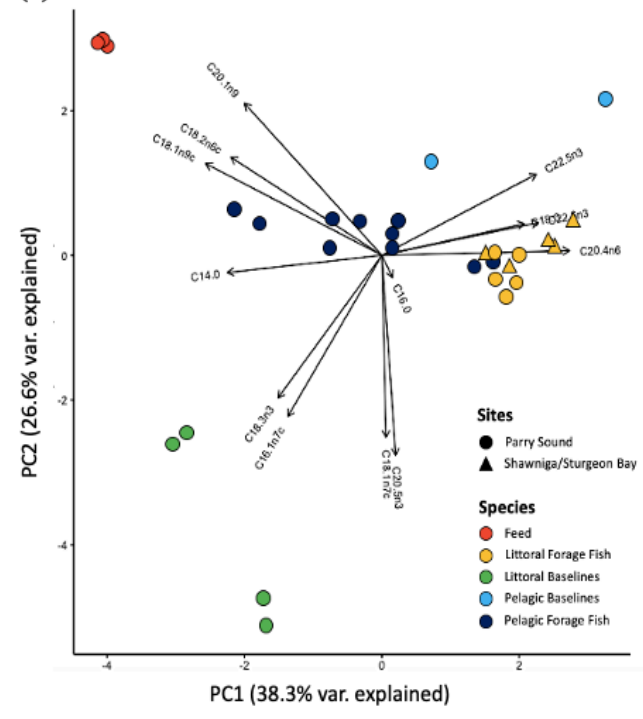

(b)

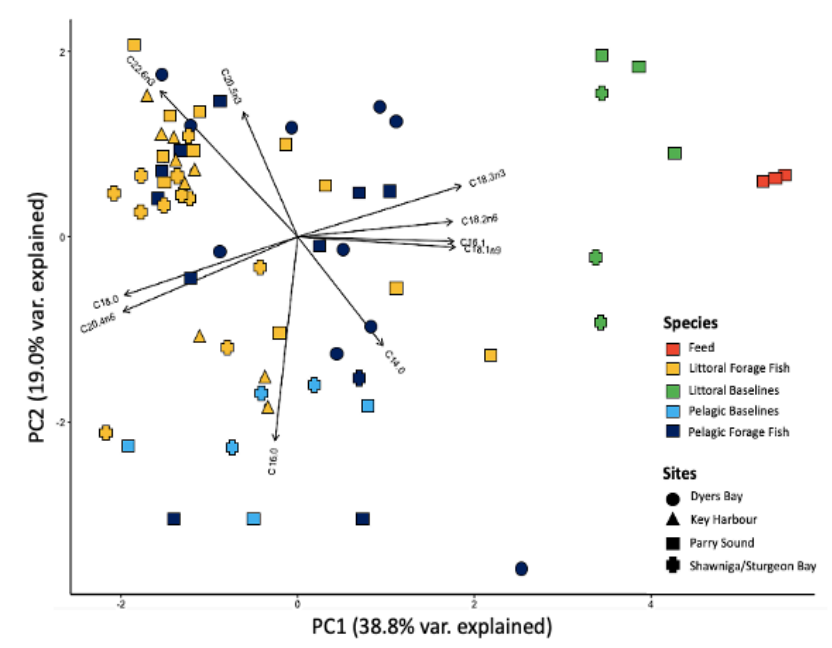


bioRxiv preprint doi: $\mathrm{https}$ //doi.org/10.1101/2020.11.09.374629; this version posted November 10,2020 . The copyright holder for this preprint (which was not certified by peer review) is the author/funder, who has granted bioRxiv a license to display the preprint in perpetuity. It is made available under aCC-BY-NC-ND 4.0 International license.

\section{$587 \quad$ Figure 3}

(a) (i)

(b)

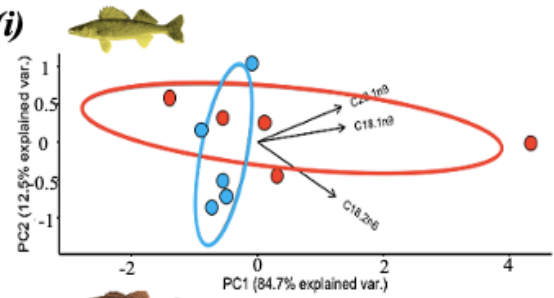

(i)

(c) (i)
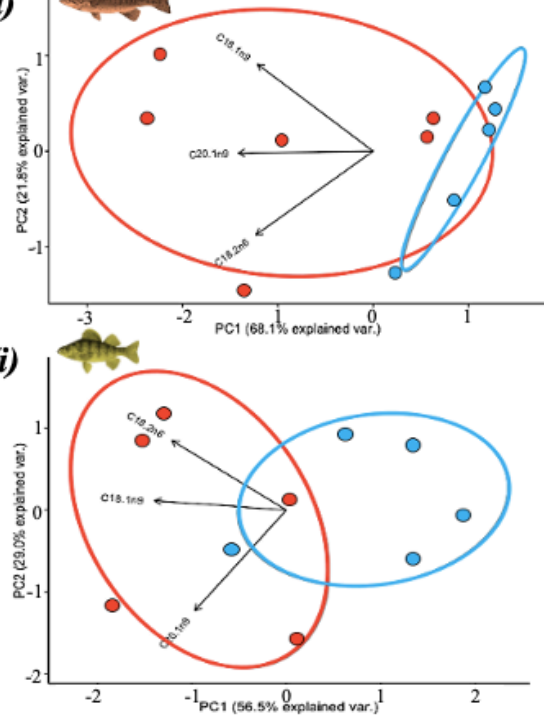

Site

Parry Sound

Shawanaga Bay 1.5

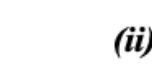

Site

Parry Sound

Shawanaga Bay

Site

Parry Sound Shawanaga Bay

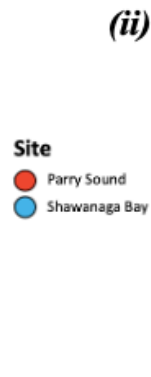

(ii)
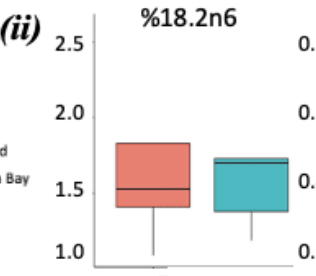

$\% 20.1 n 9$
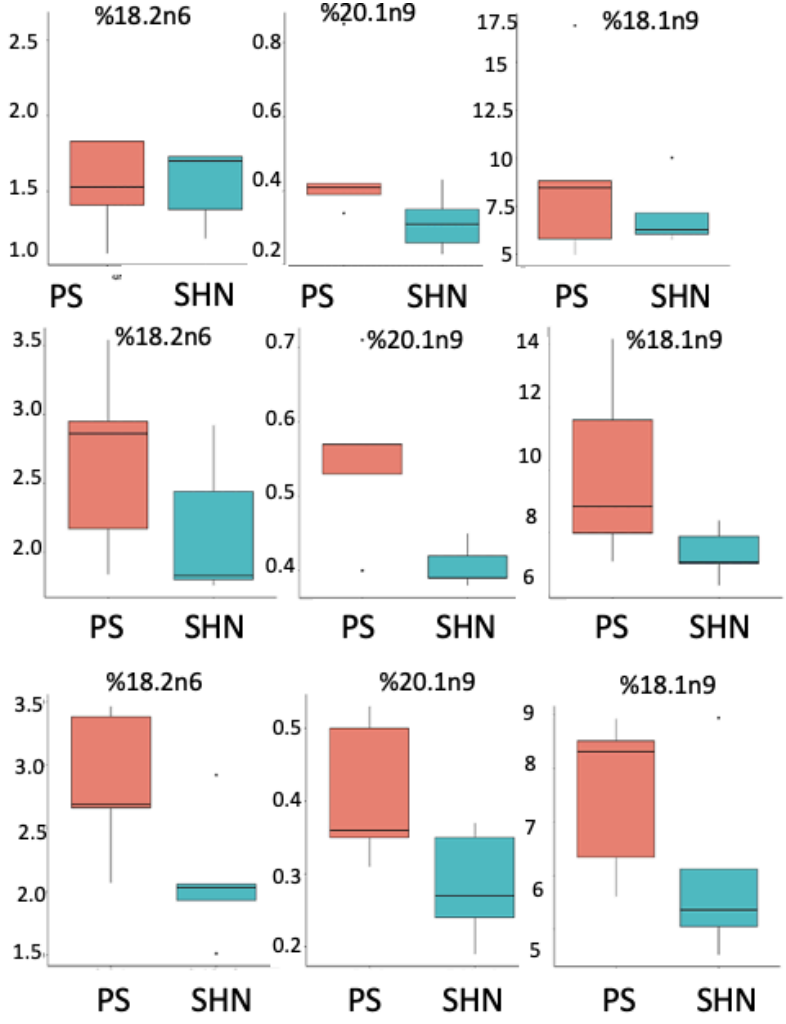
bioRxiv preprint doi: https://doi.org/10.1101/2020.11.09.374629; this version posted November 10,2020 . The copyright holder for this preprint (which was not certified by peer review) is the author/funder, who has granted bioRxiv a license to display the preprint in perpetuity. It is made available under aCC-BY-NC-ND 4.0 International license.

(a) $(i)$

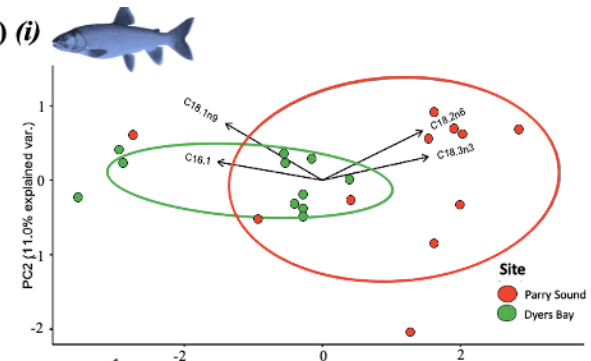

(b)

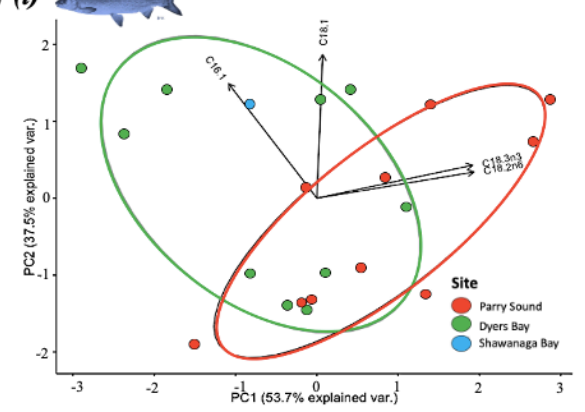

(ii)

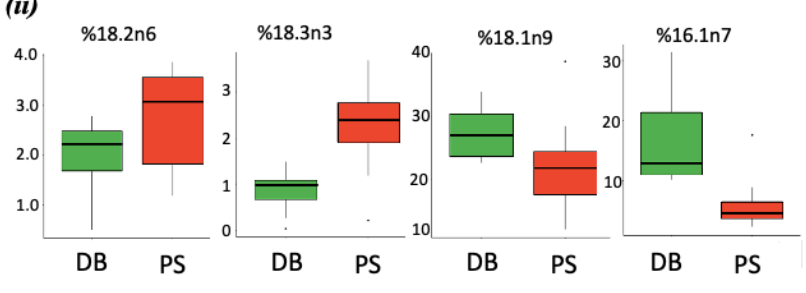

(ii)

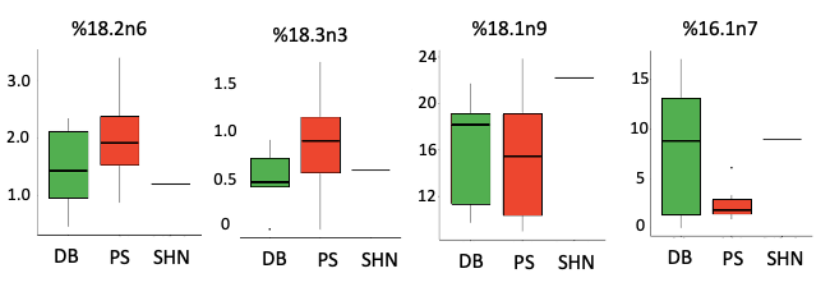

593

(c)

(d)

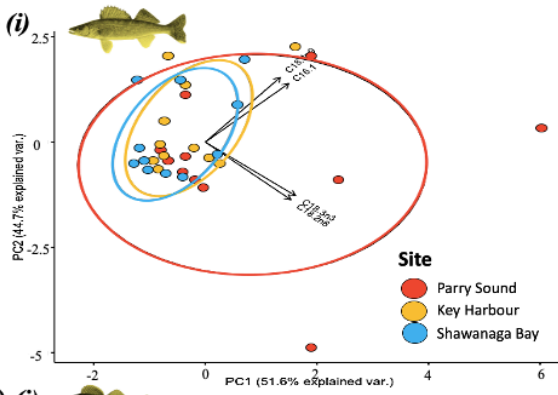

(ii)

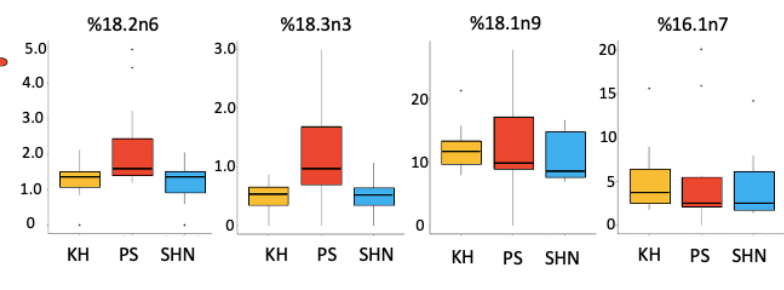

(ii)

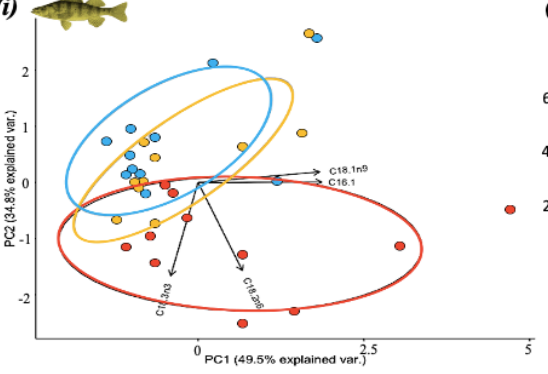

$\% 18.2 n 6$
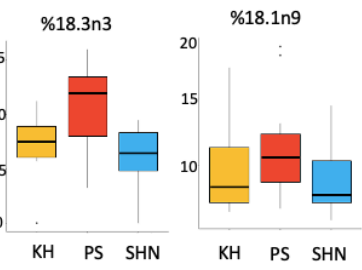

$\% 16.1$ n7

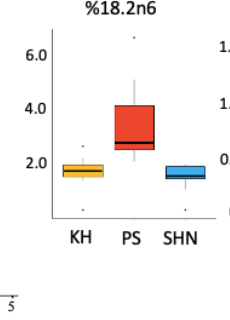

15

12

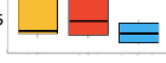

KH PS SHN

(e)

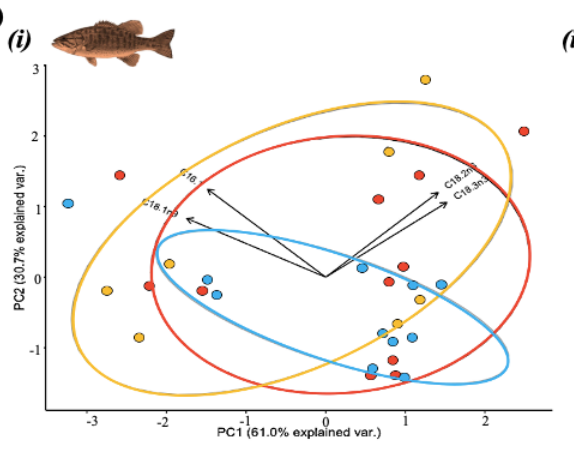

(ii)

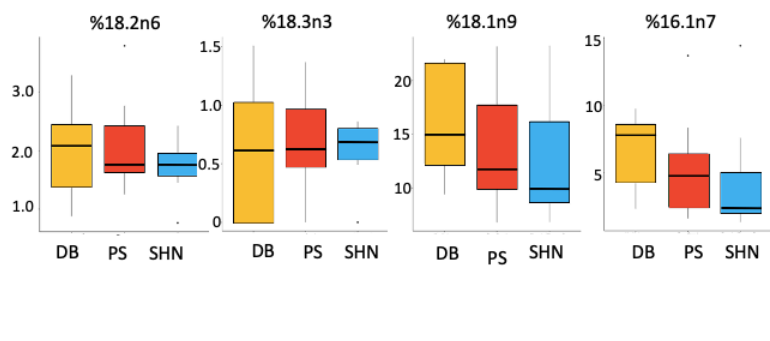


bioRxiv preprint doi: https://doi.org/10.1101/2020.11.09.374629; this version posted November 10,2020. The copyright holder for this preprint (which was not certified by peer review) is the author/funder, who has granted bioRxiv a license to display the preprint in perpetuity. It is made available under aCC-BY-NC-ND 4.0 International license.

\section{$595 \quad$ Figure 5}

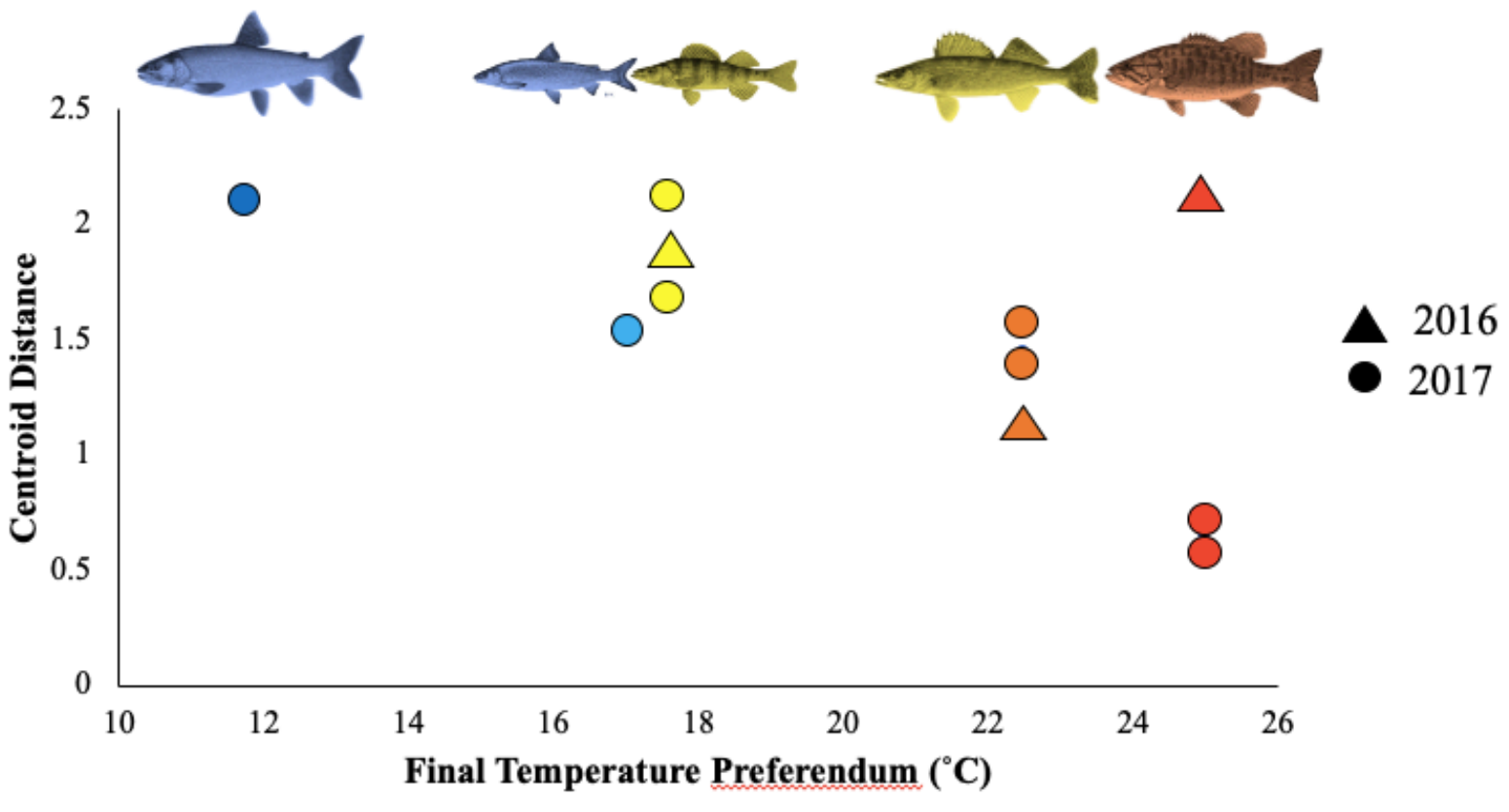


bioRxiv preprint doi: $\mathrm{https}$ //doi.org/10.1101/2020.11.09.374629; this version posted November 10,2020 . The copyright holder for this preprint (which was not certified by peer review) is the author/funder, who has granted bioRxiv a license to display the preprint in perpetuity. It is made available under aCC-BY-NC-ND 4.0 International license.

\section{$598 \quad$ Figure 6}

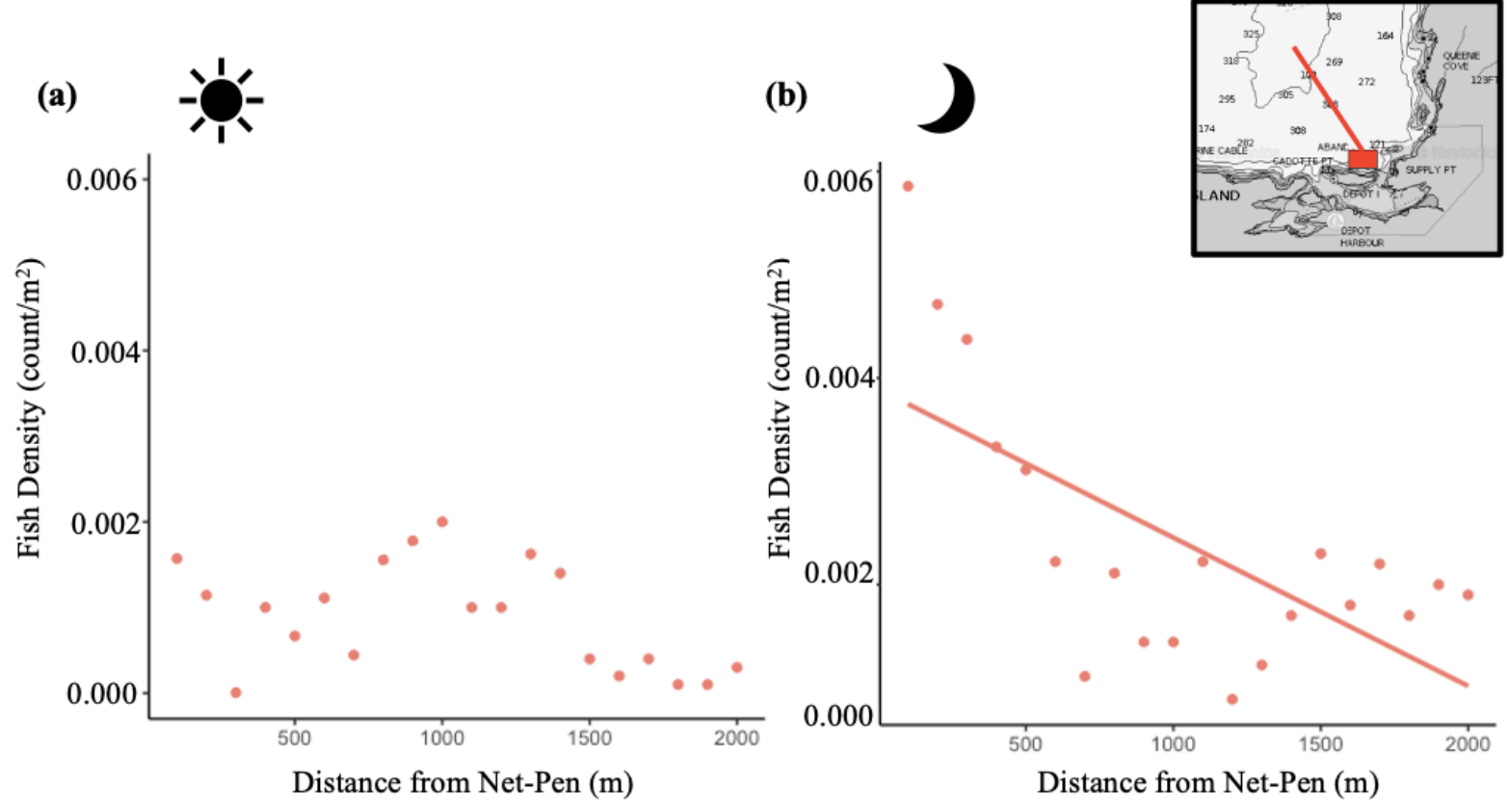

600 
bioRxiv preprint doi: https://doi.org/10.1101/2020.11.09.374629; this version posted November 10,2020 . The copyright holder for this preprint (which was not certified by peer review) is the author/funder, who has granted bioRxiv a license to display the preprint in perpetuity. It is made available under aCC-BY-NC-ND 4.0 International license.

\section{$601 \quad$ Figure 7}

602

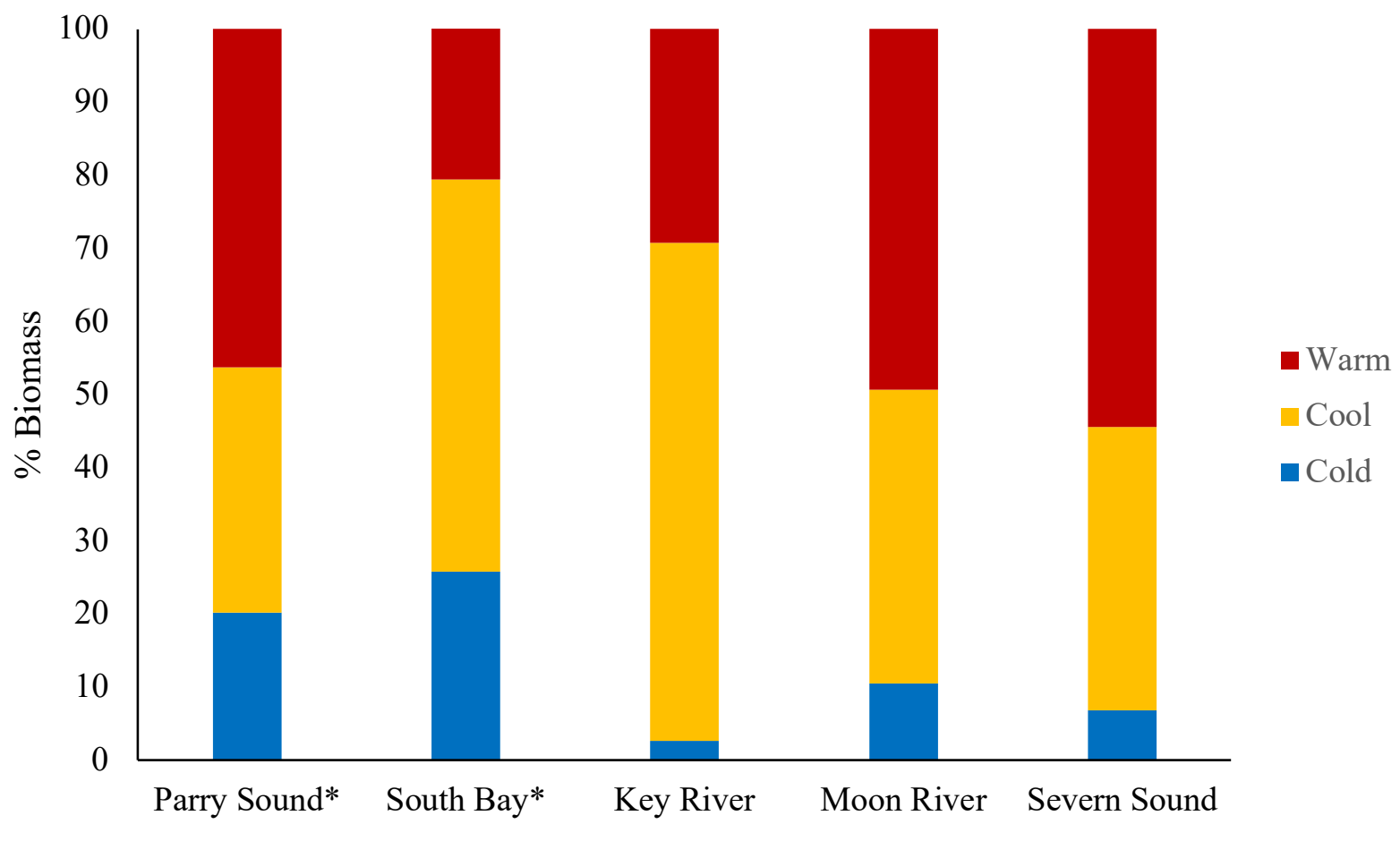

603 
Figure 8

(a)

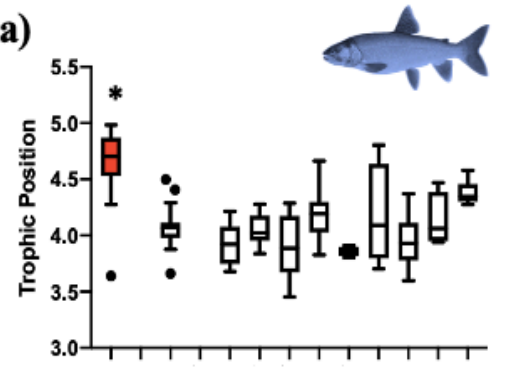

(d)

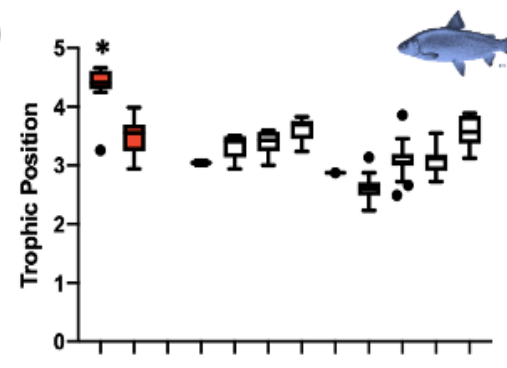

Parry Sound (off-shore net-pen aquaculture)
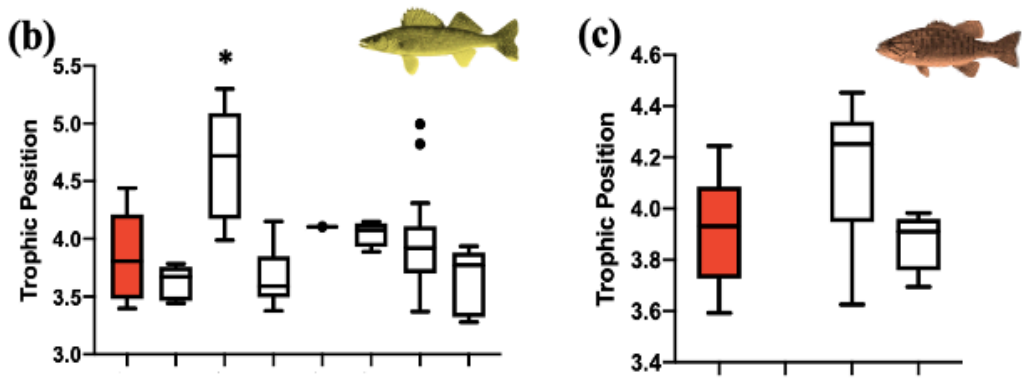

(e)

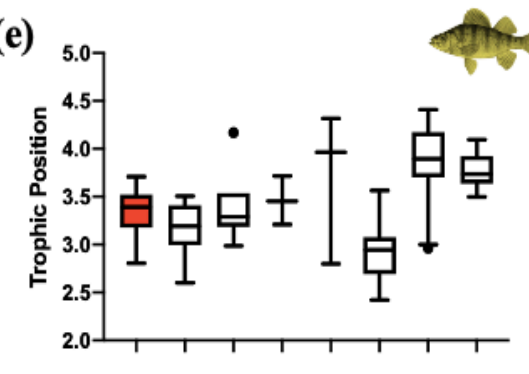

$\square$ Control Sites (no off-shore net-pen aquaculture) 